\title{
THE GENETIC ORGANISATION OF NATURAL POPULATIONS OF LOLIUM PERENNE 1. SEED AND SEEDLING CHARACTERS
}

\author{
M. D. HAYWARD and E. L. BREESE \\ Welsh Plant Breeding Station, Aberystwyth
}

Received 1.ix.65

\section{INTRODUCTION}

Perennial ryegrass, Lolium perenne $\mathrm{L}$, is one of the most important, naturally occurring, grassland species in the British Isles. It is widespread throughout Eurasia and displays considerable ecotypic differentiation in response to climatic, edaphic and biotic influences (Whyte, et al., I959). Because it is a diploid with $2 n=14$ it also lends itself to genetic and cytological studies.

The genetic organisation of a population within a species depends on its mode of reproduction (Darlington, I939). L. perenne is an outbreeding species and selection experiments (Cooper, I959) have shown that basically the genetic situation is analogous to that found by Mather and Harrison (1949) in Drosophila. Individuals were highly heterozygous while the chromosomes were relationally balanced in such a way that either over-intense selection or too-close inbreeding involved physiological disturbances, thus indicating a degree of genetic homeostasis in the populations. In fact, the general situation was that which we now accept as being fundamentally characteristic of all outbreeding organisms. A feature of the species, however, is its perenniality which is achieved by extended tiller propagation. Certain consequences in genetic organisation which might follow from this dual method of reproduction have been indicated by Breese (in press) and Breese et al. (1965).

The experiments of Cooper (loc cit) involved cultivars produced or maintained by sexual reproduction. The present investigation involves populations from an old-established grassland area and seeks to study the system of differentiation where reproduction has been largely by asexual means. This paper is concerned with the seed-set and seedling properties of crosses between populations.

\section{MATERIALS AND METHODS}

The populations under consideration originated from an area of about twenty square miles along the south-east coast of Wales known as the Monmouthshire Moors. If well managed, the area has the reputation of being valuable permanent pasture land and as such has a long history. Full details of the technique of sampling and phenotypic assessment of a total of twenty-three populations from this area, together with information of the ecological factors operating on each, has been reported by Breese and Charles ( 1962$)$. A brief description of the habitats of the ten populations used in the present study is reproduced in table 1 . 
The plants which form the basis of these populations are clones obtained by asexually propagating single tillers taken from the original habitats, so that each clone has vegetative continuity with the original sward. In each population forty tillers were taken from situations sufficiently far apart to give reasonable assurance that forty distinct genotypes were being sampled.

The crossing scheme for genetic study was in the form of a diallel cross. A first problem with regard to inter-population crosses was to sample each population adequately. Practical considerations finally dictated a maximum of 5 plants per population. These were taken at random and allocated one to each of 5 groups.

TABLE ,

Origin and habitats of the populations (see also Breese and Charles, 1962)

\begin{tabular}{|c|c|c|}
\hline $\begin{array}{l}\text { Population } \\
\text { Number }\end{array}$ & $\begin{array}{l}\text { Collection } \\
\text { Number }\end{array}$ & Location \\
\hline I & 8 & $\begin{array}{l}\text { Tredegar Park. Heavily grazed pasture containing } 60 \text { per } \\
\text { cent. perennial ryegrass. }\end{array}$ \\
\hline 2 & 3 & $\begin{array}{l}\text { Tredegar Park. Very dry, heavily grazed pasture, contain- } \\
\text { ing 6o per cent. ryegrass. }\end{array}$ \\
\hline 3 & 18 & Undy. Saltings, grazed by sheep, with a trace of ryegrass. \\
\hline 4 & 19 & Rogiet. Pasture, alternately grazed and cut for hay. \\
\hline 5 & 23 & $\begin{array}{l}\text { Nash Point. Valley bottom pasture, containing ro per } \\
\text { cent. ryegrass. }\end{array}$ \\
\hline 6 & 7 & $\begin{array}{l}\text { Tredegar Park. Meadow, cut for hay or silage, containing } \\
35 \text { per cent. ryegrass. }\end{array}$ \\
\hline 7 & 1 & $\begin{array}{l}\text { Tredegar Park. Dry grazed pasture containing } 30 \text { per } \\
\text { cent. ryegrass. }\end{array}$ \\
\hline 8 & 20 & Rogiet. Dry, cattle grazed pasture, containing 40 per \\
\hline 9 & 22 & $\begin{array}{l}\text { Nash Point. Dry cliff top pasture, grazed by sheep, con- } \\
\text { taining } 5 \text { per cent. ryegrass. }\end{array}$ \\
\hline 10 & 17 & Magor. Very wet field containing only a trace of ryegrass. \\
\hline
\end{tabular}

Each of the groups thus formed contained I plant from each of Io populations and all plants within a group were mated in all possible combinations including reciprocals. This programme should have yielded 5 parallel Io $\times$ to diallel crosses which would have afforded an estimate of sampling variation within the populations. In the event, however, insufficient seed was obtained for this purpose and all crosses between the same populations were pooled to form a single bulked $10 \times$ io diallel.

The crosses were carried out by the technique of automatic cross-pollination without emasculation (Jenkin, I931a). The proportion of seed set by selfing was tested by isolating two units per plant, each of eight inflorescences, in a glassine bag. The five plants from each population were also planted out in a polycross island where they were allowed to interpollinate at random, and this seed was used to obtain representatives of the parental populations for inclusion in the diallel.

Seed from the go inter-population bulked crosses, and from the ro intra-population polycrosses, were sown in the glasshouse in a randomised layout with 2 replications. Each of the Ioo families was represented in a replicate by a single box in which 60 heavy seeds were sown.

\section{RESULTS}

\section{(i) Self- and cross-fertility}

Studies on the self-fertility of Lolium perenne have clearly shown that the species possesses some incomplete form of a self-incompatibility mechanism (Jenkin, I93 I $b$; Beddows et al., I962). The present 
investigation reinforces the evidence, for the percentage seed set on selfing under the artificial conditions of the experiment was extremely low (see table 2).

An analysis of variance of selfing data is also presented in table 2. The residual error item is a measure of the variation between units within a genotype. The high measure of this value can be considered as an indication that the potentiality to set seed by selfing is influenced to a large degree by environmental conditions. When tested against

TABLE 2

Percentage seed-set on selfing expressed as the average of two units per genotype

\begin{tabular}{|c|c|c|c|c|c|c|c|c|c|c|}
\hline \multirow{2}{*}{ Genotypes } & \multicolumn{10}{|c|}{ Populations } \\
\hline & I & 2 & 3 & 4 & 5 & 6 & 7 & 8 & 9 & Io \\
\hline I & $0 \cdot 14$ & 0.07 & $3 \cdot 25$ & $2 \cdot 8 I$ & $0 \cdot 0$ & 0.0 & $0 \cdot 82$ & $0 \cdot 13$ & $I \cdot 34$ & 0.0 \\
\hline 2 & $5 \cdot 63$ & $5 \cdot 49$ & $0 \cdot 14$ & 0.4 & $7 \cdot 05$ & $7 \cdot 03$ & $0 \cdot 0$ & 0.35 & 0.15 & 0.0 \\
\hline 3 & 0.08 & 0.73 & $6 \cdot 33$ & $0 \cdot 0$ & 0.0 & $0 \cdot 28$ & $2 \cdot 49$ & $0 \cdot 18$ & - & 0.26 \\
\hline 4 & $0 \cdot 32$ & $0 \cdot 0$ & $0 \cdot 24$ & 0.55 & 0.45 & 0.23 & $I \cdot O I$ & $0 \cdot 0$ & 0.0 & 0.0 \\
\hline 5 & $0 \cdot 09$ & $0 \cdot 0$ & $0.0^{\circ}$ & $0 \cdot 39$ & $0 \cdot 0$ & 0.07 & $5 \cdot 10$ & $0 \cdot 0$ & $0 \cdot 04$ & $0 \cdot 0$ \\
\hline
\end{tabular}

Analysis of variance

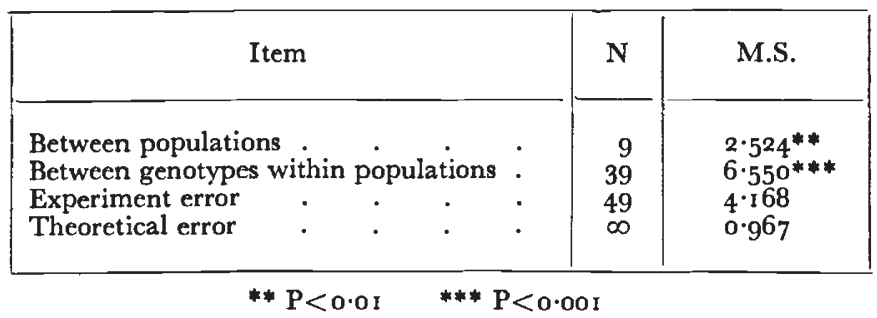

the theoretical error obtainable in the use of the angular transformation, all of the items of the analysis are significant.

The seed set on crossing, expressed as the percentage florets setting heavy seed, is shown in table 3, each value being the mean of the five single genotype crosses going to make up the family. The data were analysed by the method of Yates (1947), as no direct comparison can be made in the absence of any diagonal values. The results of the application of this analysis, after angular transformation of the basic data, are presented in table 3 . In the partitioning of the diagonal sums, the mean square for the populations is significantly greater than the remainder $(a)$ indicating that real differences exist between the populations which are consistent for all crosses. A comparison of the mean squares for the populations with remainder $(b)$ in the diagonal differences part of the analysis indicates a consistent difference in behaviour when the populations are used as male or female parents. The mean square of remainder (a) does not differ significantly from that 
of remainder $(b),(\mathbf{P}=\mathbf{I} \cdot 0-0 \cdot \mathrm{I})$, revealing that the similarity between reciprocal crosses of the same parent is no greater than that between crosses of different parents after independently allowing for the average effects of the male and female.

\section{TABLE 3}

Percentage seed-set on crossing (i.e. heavy seed per roo florets). Means of the five crosses making up each population $F_{1}$

\begin{tabular}{|c|c|c|c|c|c|c|c|c|c|c|}
\hline q & I & 2 & 3 & 4 & 5 & 6 & 7 & 8 & 9 & Io \\
\hline I & $\ldots$ & $5^{\circ} 0$ & $6 \cdot 7$ & $8 \cdot 4$ & $5 \cdot 8$ & $5 \cdot 8$ & 9.5 & 48 & 49 & 0.7 \\
\hline 2 & $7 \cdot 2$ & $\ldots$ & $6 \cdot 8$ & $5 \cdot 3$ & 3.7 & I 34 & $2 \cdot 4$ & 94 & $5 \cdot 6$ & $2 \cdot 2$ \\
\hline 3 & $5^{\circ} 0$ & $2 \cdot 3$ & $\ldots$ & $3^{\circ} 0$ & 3.7 & $3 \cdot 2$ & $5 \cdot 8$ & $7 \cdot \mathrm{I}$ & $2 \cdot 0$ & 0.4 \\
\hline 4 & I I 6 & $7 \cdot 0$ & I I 6 & $\ldots$ & 3.9 & $9 \cdot I$ & I. 9 & $6 \cdot 3$ & I. 4 & $0 \cdot 0$ \\
\hline 5 & $6 \cdot 1$ & 4.4 & $7 \cdot 7$ & 4.4 & $\ldots$ & 3.4 & $2 \cdot 5$ & 3.5 & I. 6 & 0.9 \\
\hline 6 & II 7 & $1 \cdot 7$ & 4.5 & $6 \cdot 8$ & $5^{\circ} 0$ & $\ldots$ & $7 \cdot 5$ & 6.6 & 3.7 & $4 \cdot 4$ \\
\hline 7 & I I 6 & $7 \cdot 3$ & I 7.6 & $3 \cdot 0$ & $6 \cdot I$ & II $\cdot 8$ & $\ldots$ & $7 \cdot 7$ & $4 \cdot 9$ & $5 \cdot 3$ \\
\hline 8 & 12.7 & $8 \cdot 9$ & II $\cdot 5$ & $6 \cdot 3$ & $4 \cdot 9$ & $6 \cdot 7$ & $12 \cdot 0$ & $\ldots$ & $6 \cdot 2$ & 2.4 \\
\hline 9 & 19.3 & 1 3.8 & I 53 & 1 3.4 & $14 \cdot 6$ & I 5.3 & $2 I \cdot I$ & $16 \cdot 2$ & $\ldots$ & 5.8 \\
\hline IO & $7 \cdot 6$ & 6.7 & & 3.5 & II I I & 10.7 & $9 \cdot 9$ & $7 \cdot 7$ & $2 \cdot 2$ & $\cdots$ \\
\hline
\end{tabular}

Analysis of variance

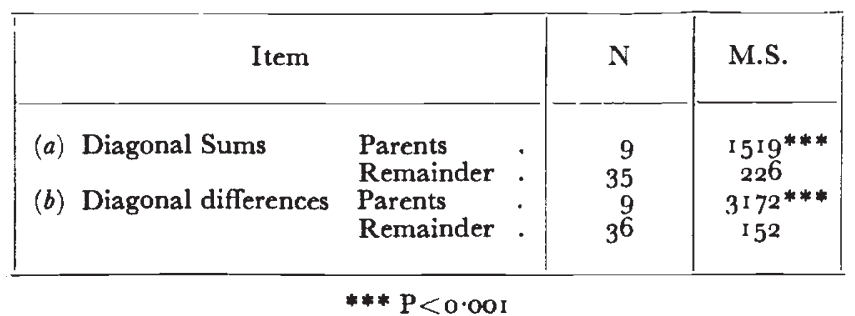

Reanalysis of the percentage seed set on crossing into male and female effects, together with the ormmission of array 10 .

\begin{tabular}{|c|c|c|c|c|c|}
\hline \multirow{2}{*}{ Item } & & \multicolumn{2}{|c|}{ Complete data } & \multicolumn{2}{|c|}{ Omitting array ro } \\
\hline & & $\mathbf{N}$ & M.S. & $\mathbf{N}$ & M.S. \\
\hline $\begin{array}{l}\text { Females } \\
\text { Males } \\
\text { Pooled remainder }\end{array}$ & $\dot{\dot{\varphi}}$ & $\begin{array}{r}9 \\
9 \\
7 \mathrm{I}\end{array}$ & $\begin{array}{l}2343^{* * *} \\
2349^{* * *} \\
188^{*}\end{array}$ & $\begin{array}{r}8 \\
8 \\
55\end{array}$ & $\begin{array}{l}2564^{* * * *} \\
1218^{* * *} \\
164\end{array}$ \\
\hline
\end{tabular}

The sums of squares for the populations in the diagonal sums and differences may be repartitioned into separate male and female effects by the method of least squares as proposed by Yates (loc cit). The results of this analysis are presented in table 3. This repartitioning is almost equal between the males and females indicating that the differences which exist in the seed setting potential can be attributed to both sexes. 
The differences between the populations when used as male parents may be attributable to the variation in pollen fertility. Population Io for instance was virtually male sterile, the anthers in general being non-dehiscent or producing very little viable pollen (Stephens, personal communication). The effects of this are indicated in the generally low seed-set of the crosses involving this population as a male parent (see table 3). To investigate whether the low male fertility of population Io was mainly responsible for the male effects in the analysis, the data were re-analysed omitting array ı. As can be seen from table 3 the differences between the male parents are still significant, but the redistribution shows that the female parents are probably having the greater effect.

TABLE 4

Mean percentage germination

\begin{tabular}{|c|c|c|c|c|c|c|c|c|c|c|}
\hline 0 & I & 2 & 3 & 4 & 5 & 6 & 7 & 8 & 9 & Io \\
\hline I & 54 & 89 & $9 \mathrm{I}$ & 67 & 68 & 77 & 77 & 83 & 73 & 64 \\
\hline 2 & 82 & 45 & 80 & 82 & 53 & 90 & 87 & 82 & 82 & 90 \\
\hline 3 & 79 & 64 & 37 & 69 & 90 & 85 & 85 & 87 & 75 & 87 \\
\hline 4 & $9^{2}$ & 92 & 82 & $5^{8}$ & 80 & 93 & 72 & 84 & 100 & $9^{\mathrm{I}}$ \\
\hline 5 & 84 & 92 & 92 & 82 & 27 & 73 & 70 & 83 & 60 & 65 \\
\hline $\overrightarrow{6}$ & 63 & 52 & 85 & 84 & 85 & 57 & $8_{5}$ & $8 \mathrm{I}$ & 83 & 73 \\
\hline 7 & 87 & 68 & 83 & 89 & $7 \mathrm{I}$ & 82 & $5^{8}$ & 87 & 88 & 82 \\
\hline 8 & 86 & 89 & 95 & 78 & 85 & 82 & 87 & 67 & ${ }_{96}$ & 84 \\
\hline 9 & 84 & 67 & $8 \mathrm{I}$ & 55 & 70 & 72 & 80 & 83 & 29 & 83 \\
\hline 10 & 70 & 80 & 94 & 94 & $9^{2}$ & 89 & 83 & $9^{\mathrm{I}}$ & 59 & 55 \\
\hline
\end{tabular}

These results contrast markedly with those of Beddows et al. (loc cit). In the first place, both selfing and crossing values are on the average much lower ( $\mathrm{I} \cdot 09 \mathrm{v} \cdot \mathrm{I} \cdot 3 \mathrm{I}$ and $6 \cdot 96 \cdot v \cdot 4^{\circ} \cdot 0$ respectively). Secondly, whereas these authors found that differences between parents were mainly due to maternal effects, here there is good evidence that there are also differences in male fertilities.

It should be emphasised that the effects noted here are significant differences between populations. There are also differences between genotypes within populations resulting in some instances in no crossed seed being produced, thus necessitating the use of a bulked diallel and making difficult the complete analysis of data from individual crosses. The significance of these results will be discussed later.

\section{(ii) Germination}

The number of germinating seed was recorded twenty-four days after sowing. The results, expressed as percentage germination are shown in table 4. The basic data have been transformed to arcsin angles before applying the analysis of variance of a diallel table as devised by Hayman (1954a), the results of which are given in table 5 . 
A comparison of the error variances by Bartlett's test for the homogeneity of variances is of borderline significance $(P=0 . I-0.05)$, thus each main effect is tested against its corresponding interaction with the blocks. The significance of item $(a)$ indicates the existence of genetical variation between the populations. The $(b)$ main effect has been split into its component parts; $\left(b_{1}\right)$ being a measure of the mean dominance

\section{TABLE 5}

Analysis of variance of the diallel table of percentage germination (after angular transformation)

\begin{tabular}{|c|c|c|c|}
\hline Item & $\mathbf{N}$ & M.S. & V.R. \\
\hline $\begin{array}{l}a \\
b_{1} \\
b_{2} \\
b_{3}\end{array}$ & $\begin{array}{r}9 \\
1 \\
9 \\
35\end{array}$ & $\begin{array}{c}222 \\
7859 \\
59 \\
79\end{array}$ & $\begin{array}{l}7 \cdot 33^{* *} \\
24^{1} 7^{*} \\
3.54^{*} \\
1.89^{*}\end{array}$ \\
\hline$b$ & 45 & 248 & $6 \cdot 90^{* * *}$ \\
\hline $\begin{array}{l}c \\
d\end{array}$ & $\begin{array}{r}9 \\
3^{6}\end{array}$ & $\begin{array}{l}146 \\
134\end{array}$ & $\begin{array}{l}1 \cdot 73 \\
2 \cdot 07^{*}\end{array}$ \\
\hline$t$ & 99 & & \\
\hline $\begin{array}{l}B \\
B a \\
B b_{1} \\
B b_{2} \\
B b_{3}\end{array}$ & $\begin{array}{r}1 \\
9 \\
1 \\
9 \\
35\end{array}$ & $\begin{array}{r}25 \\
30 \\
3 \\
16 \\
4^{1}\end{array}$ & \\
\hline$B b$ & 45 & $3^{6}$ & \\
\hline $\begin{array}{l}B c \\
B d\end{array}$ & $\begin{array}{r}9 \\
3^{6}\end{array}$ & $\begin{array}{l}84 \\
65\end{array}$ & \\
\hline$B t$ & 99 & 50 & \\
\hline Total & I99 & & \\
\hline
\end{tabular}

deviation, $\left(b_{2}\right)$, a further dominance deviation due to asymmetrical gene distribution, and $\left(b_{3}\right)$ an estimate of any specific interaction. In the presence of symmetrical gene distribution $\left(b_{3}\right)$ together with $\left(b_{1}\right)$ provide a test of dominance equivalent to the overall $(b)$ item.

Against their own heterogeneity items, all these dominance components are significant, but $\left(b_{1}\right)$ is by far the largest item in the analysis and is significantly larger than the other dominance items. This 
would signify considerable heterosis in crosses between populations but it must be remembered that seed from crosses within populations was harvested under different environmental conditions as compared with crosses between populations. Effects due to environmental differences will therefore be confounded with deviations attributable to mean dominance, and this large $\left(b_{1}\right)$ item must be interpreted with caution.

The $(c)$ and $(d)$ items are a measure of reciprocal differences $(c)$ being the average maternal effect of each line, whilst $(d)$ measures reciprocal differences not ascribable to $(c)$. These items are of the same order and $(d)$ is significant against its own error item indicating some form of reciprocal differences which are not constant throughout the array and is hence most easily interpreted as being an expression of nuclear/cytoplasmic interaction. It will be observed that variation due to $\left(b_{2}\right)$ and $\left(b_{3}\right)$ dominance effects is no greater than differences ascribable to this interaction.

The data may be analysed further by the methods of Jinks (1954) and Hayman (1954b) which have been elaborated by Dickinson and Jinks (1956) to include a diallel cross between heterozygous parents. These methods make use of the array variances $\left(\mathrm{V}_{r}\right)$ and the covariances $\left(W_{r}\right)$ within arrays of family means with the non-recurrent parent.

At this stage it might be well to pause and consider the implications of using non-inbred parents in investigating genetical differences between populations. If the sampling is sufficient, the diallel cross will measure the effects of those genes by which the populations differ. It will take no account of the zygotic state (whether homozygous or heterozygous) of genes controlling the expression which is common to all populations. Thus, although we know that the outbreeding system in ryegrass ensures a high level of heterozygosity, this does not mean that the genes by which the populations differ will involve heterozygous arrangements. Indeed, if differentiation between populations is to survive sexual reproduction, some genetic fixation must occur. Normally this involves homozygosis at some of the gene loci controlling expression, which is in itself a consequence of the selection and mating together of like phenotypes (Breese, 1956). Rarely of course, the distinction between differentially adapted populations may depend on relationally balanced gene sequences which are preserved by special devices, as for instance in the permanent structural heterozygotes of the Oenothera complex of species (Darlington and Mather, 1949). Usually, however, we can expect evolutionary distinct populations to differ predominantly by homozygous gene loci. On a priori grounds, therefore, we may expect crosses between populations to be equivalent, for analysis purposes, to crosses between "homozygous only" parents. But, as pointed out by Dickinson and Jinks (loc cit) the $\mathrm{W}_{r} / \mathrm{V}_{r}$ analysis provides a test as to the validity of this assumption and thus also provides information as to the degree of genetic differentiation.

In the experiment the values of $\mathrm{W}_{r}$ and $\mathrm{V}_{r}$ have been calculated 
from family means averaged over blocks and reciprocals. Fig. I shows graphically the regression of $\mathrm{W}_{r}$ on $\mathrm{V}_{r}(b=0.72 \pm 0.1 \mathrm{I})$ which is highly significant but, because of the considerable scatter of points, does not deviate significantly from unity. The regression line intercepts the $\mathrm{W}_{r}$ axis at a significant distance from the origin $(\mathrm{P}=0.05-0.02)$ but no correction for the environmental component has been applied, so the deviation will be somewhat less than this. However, the graph certainly indicates high dominance with some suggestion of overdominance which accords with the high $\left(b_{1}\right)$ value in the previous analysis. The points do not fall clearly into the triangular pattern

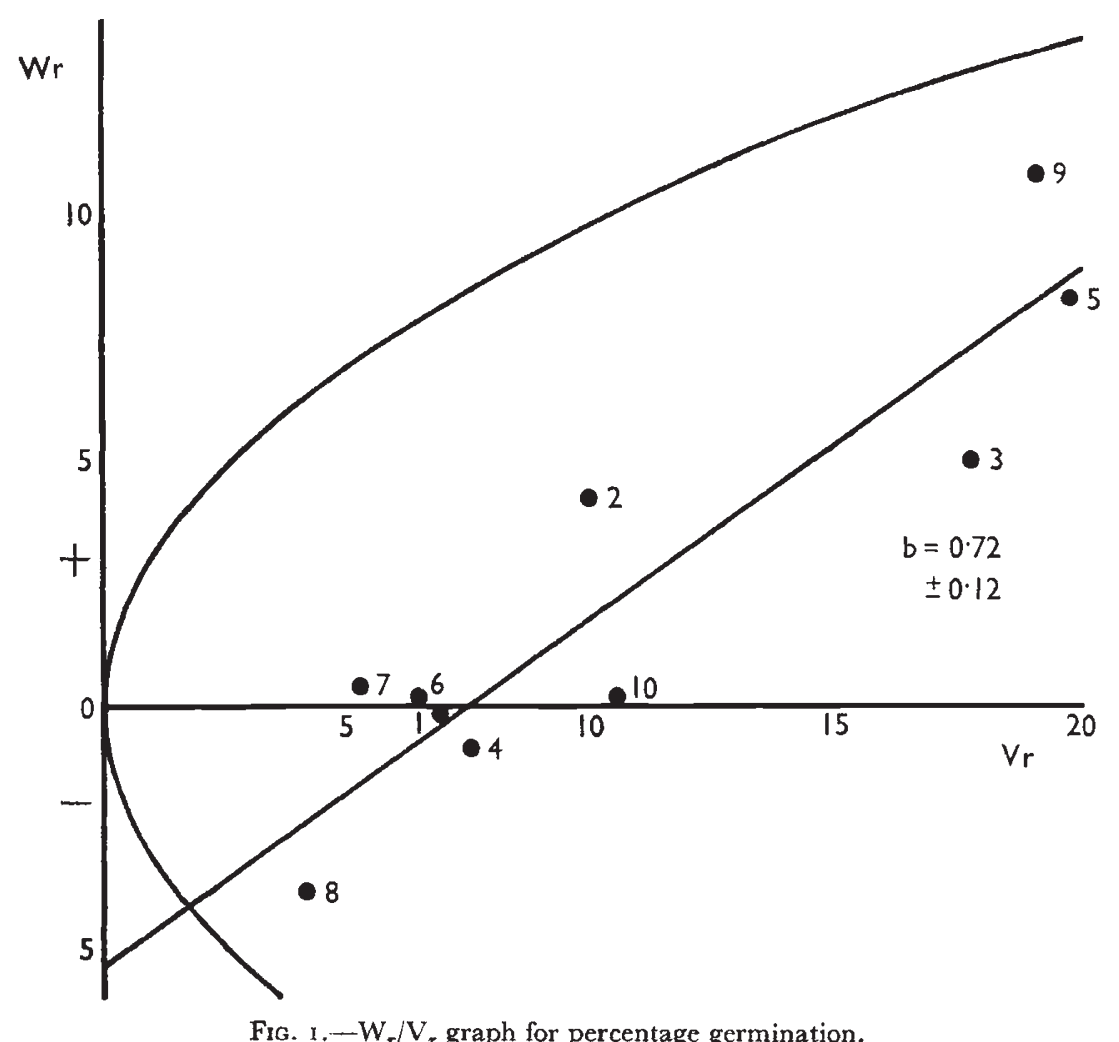

FIG. 1. $-W_{r} / V_{r}$ graph for percentage germination.

which would indicate a high frequency of heterozygosity (see Dickinson and Jinks, loc cit), and the scatter may well be a reflection of the reciprocal differences detected in the analysis of variance. It must also be remembered that sampling variation within the populations may add to this scatter.

There is a strong negative correlation of parental germination values and the order of points along the regression line $\left(r=-0 \cdot 9^{8}\right.$ and $\mathrm{P}=0.00 \mathrm{I}$ ) indicating that dominance is in the direction of high germination capacity. The significance of these results is discussed later. 


\section{(iii) Leaf and tiller number}

The number of leaves on the seedlings was recorded on fifteen plants per family for each block thirty-three days after sowing. Tiller number was recorded at forty days. The mean leaf and tiller numbers are presented in table 6 and the corresponding analyses of variance in table 7. Each main effect has been tested against its appropriate interaction item as the error variances are heterogeneous (for leaf number $\chi^{2}[5]=16.8$ and $P=0.01-0.001 ;$ for tiller number $\chi^{2}[5]=9^{2} \cdot 9$ and $\left.\mathrm{P}<0.001\right)$.

TABLE 6

Mean leaf and tiller number (upper and lower values respectively)

\begin{tabular}{|c|c|c|c|c|c|c|c|c|c|c|}
\hline & I & 2 & 3 & 4 & 5 & 6 & 7 & 8 & 9 & 10 \\
\hline \multirow[t]{2}{*}{ I } & $10 \cdot 3$ & $12 \cdot 3$ & $1 \mathrm{I} \cdot 4$ & 9.5 & $10^{\circ} \mathrm{I}$ & II 0 & 9.2 & $10 \cdot 0$ & $\begin{array}{lll} & 9\end{array}$ & 10.7 \\
\hline & $7 \cdot 2$ & $9^{6} 6$ & $8 \cdot 9$ & $7 \cdot 3$ & $7 \cdot 2$ & $8 \cdot 4$ & 7.0 & $7 \cdot 3$ & 8.9 & 7.5 \\
\hline \multirow[t]{2}{*}{2} & II 3 & $10 \cdot 3$ & $12 \cdot 0$ & $9^{\circ} 0$ & $12 \cdot 0$ & 11.4 & II 2 & $11 \cdot 7$ & $11 \cdot 7$ & $13 \cdot 1$ \\
\hline & $8 \cdot 1$ & $8 \cdot 1$ & $8 \cdot 7$ & $6 \cdot I$ & $8 \cdot 7$ & $8 \cdot 7$ & 9.5 & 8.4 & 8.8 & $9 \cdot 7$ \\
\hline \multirow[t]{2}{*}{3} & 12.5 & $12 \cdot 2$ & I0.9 & II $\cdot 9$ & $12 \cdot 1$ & 144 & II. 4 & $11 \cdot 8$ & 10.7 & 115 \\
\hline & 9.7 & $9 \cdot 2$ & 7.8 & 8.9 & $9^{\cdot 2}$ & $9 \cdot 8$ & $8 \cdot 2$ & $8 \cdot 7$ & $8 \cdot 3$ & $7 \cdot 3$ \\
\hline \multirow[t]{2}{*}{4} & 116 & $9 \cdot 8$ & $12 \cdot 6$ & $12 \cdot 0$ & 114 & 12.5 & 13.6 & $12.9^{\circ}$ & $8 \cdot 9$ & $9^{\cdot 8}$ \\
\hline & $9^{-I}$ & 70 & 9.3 & 8.7 & 8.7 & 9.1 & $10 \cdot 3$ & $9^{\circ} 0$ & 6.4 & $7 \cdot 3$ \\
\hline \multirow[t]{2}{*}{5} & 13.5 & 11.7 & 12.8 & 12.5 & 13.2 & ${ }^{I I} \cdot 8$ & $9^{\cdot 2}$ & $12 \cdot 3$ & 10.4 & $11 \cdot 0$ \\
\hline & 10.5 & $8 \cdot 2$ & 9.7 & $9 \cdot 3$ & 10.6 & 8.9 & $7 \cdot I$ & $9^{\circ} \mathrm{I}$ & $7 \cdot 8$ & $8 \cdot 6$ \\
\hline \multirow[t]{2}{*}{6} & $\begin{array}{l}9 \cdot 6 \\
6 \cdot 0\end{array}$ & 13.8 & $\begin{array}{r}11 \cdot 4 \\
8.2\end{array}$ & $12 \cdot 3$ & 12.6 & 12.5 & 12.6 & 13.5 & 13.7 & $10 \cdot 6$ \\
\hline & I. & $\begin{array}{r}90 \\
12.0\end{array}$ & $\begin{array}{r}0 \cdot 3 \\
12 \cdot 2\end{array}$ & $\begin{array}{r}90 \\
4.0\end{array}$ & $\begin{array}{r}93 \\
\end{array}$ & 93 & $\begin{array}{r}90 \\
12.2\end{array}$ & 9.8 & 1000 & $\begin{array}{r}7^{\circ} \\
\end{array}$ \\
\hline 7 & 8.7 & 8.9 & 94 & $9 \cdot I$ & $\begin{array}{r}9.9 \\
\end{array}$ & $\begin{array}{l}10 \cdot 5 \\
\end{array}$ & 9.6 & $9 \cdot 2$ & $8 \cdot 3$ & $\begin{array}{r}1.5 \\
8.5\end{array}$ \\
\hline \multirow[t]{2}{*}{8} & 13.7 & 12.7 & $13 \cdot I$ & $12 \cdot I$ & II $\cdot 2$ & $13 . \overline{8}$ & $11 \cdot 5$ & $I I \cdot 5$ & 12.6 & $12 \cdot 6$ \\
\hline & $9 \cdot 7$ & $9 \cdot 3$ & $9^{\cdot 6}$ & 8.7 & $8 \cdot 3$ & 10.7 & $8 \cdot 4$ & $8 \cdot 2$ & $8 \cdot 8$ & 8.6 \\
\hline \multirow[t]{2}{*}{9} & 11.5 & IOII & 9.4 & 9.6 & $10 \cdot 3$ & $110^{\circ}$ & II 0 & $I I \cdot 2$ & $9 \cdot 1$ & $8 \cdot 3$ \\
\hline & 8.1 & $7^{\circ} 0$ & $7 \cdot 0$ & 6.6 & $7 \cdot 2$ & $8 \cdot 6$ & $8 \cdot 2$ & $8 \cdot I$ & 6.0 & 5.8 \\
\hline \multirow[t]{2}{*}{10} & 10.8 & $9^{\circ} 0$ & 12.1 & $12 \cdot 6$ & 119 & $10 \cdot 8$ & $11 \cdot 2$ & II $\cdot 2$ & $11 \cdot 5$ & $8 \cdot 7$ \\
\hline & $8 \cdot 3$ & $6 \cdot 5$ & $8 \cdot 7$ & $9^{\circ} 0$ & $8 \cdot 7$ & $8 \cdot 0$ & 8.4 & $8 \cdot 2$ & $8 \cdot I$ & 6.4 \\
\hline
\end{tabular}

From the analysis of variance there is good evidence of genetic variation between the populations for both characters (item $a$ ), together with an indication of the existence of dominance (item $b$ ). Since of the dominance components only $\left(b_{3}\right)$ is significant, the dominance is ambidirectional, or its expression is confounded with other effects. However, none of the dominance components is higher than the items measuring reciprocal differences, so that they cannot be regarded as making an important contribution to the variation. Tested against their own interaction items, only $(d)$ in the case of leaf number achieves significance. There is thus no evidence of general maternal effects, but some indication of specific reciprocal differences.

The genetical situation may again be investigated by the $\mathrm{W}_{r} / \mathrm{V}_{r}$ analysis as outlined in the previous section. The two graphs are presented in fig. 2. In both instances the regression of $\mathrm{W}_{r}$ on $\mathrm{V}_{r}$ is non-significant, indicating either the absence of dominance or of intense genic interaction. If the former were true, the points should 
cluster around the position on the limiting parabola of $\mathrm{W}_{r}=2 \mathrm{~V}_{r}$. This does not appear to be the case, so that some complicated form of non-additive genetic variation may be present. This situation could well arise where heterozygosity was present at a number of loci, some of which exhibit epistasis, and where the gene distribution was nonrandom (see Hill, I964). However, the analysis of variance indicates

TABLE 7

Analysis of variance of the diallel table of leaf and tiller number

\begin{tabular}{|c|c|c|c|}
\hline Item & N. & $\begin{array}{l}\text { Leaf number } \\
\text { M.S. }\end{array}$ & $\begin{array}{c}\text { Tiller number } \\
\text { M.S. }\end{array}$ \\
\hline $\begin{array}{l}a \\
b_{1} \\
b_{2} \\
b_{3}\end{array}$ & $\begin{array}{r}9 \\
\mathbf{1} \\
9 \\
35\end{array}$ & $\begin{array}{l}2606^{* *} \\
744 \\
546 \\
517^{* *}\end{array}$ & $\begin{array}{l}8 \cdot 52 * * \\
2 \cdot 12 \\
1 \cdot 59 \\
1 \cdot 69 * * *\end{array}$ \\
\hline$b$ & 45 & $528^{*}$ & $1 \cdot 68 * *$ \\
\hline $\begin{array}{l}c \\
d\end{array}$ & 39 & $\begin{array}{l}782 \\
655^{*}\end{array}$ & $\begin{array}{l}2 \cdot 35 \\
1.63\end{array}$ \\
\hline$t$ & 99 & & \\
\hline $\begin{array}{l}B \\
B a \\
B b_{1} \\
B b_{2} \\
B b_{3}\end{array}$ & $\begin{array}{r}\mathbf{I} \\
9 \\
\mathbf{I} \\
9 \\
35\end{array}$ & $\begin{array}{r}828 \mathrm{r} \\
428 \\
143 \\
757 \\
185\end{array}$ & $\begin{array}{r}25 \cdot 77 \\
1.42 \\
0.40 \\
1 \cdot 94 \\
0.03\end{array}$ \\
\hline$B b$ & 45 & 299 & 0.67 \\
\hline $\begin{array}{l}B c \\
B d\end{array}$ & $\begin{array}{r}9 \\
35\end{array}$ & $\begin{array}{l}343 \\
347\end{array}$ & $\begin{array}{l}1 \cdot 15 \\
1 \cdot 08\end{array}$ \\
\hline$B t$ & 99 & 329 & 0.93 \\
\hline Total & 199 & & \\
\hline
\end{tabular}

that these effects are relatively unimportant compared with the large additive differences, so that further analysis of $\mathrm{W}_{r}$ 's and $\mathrm{V}_{r}$ 's on a block by block basis is unjustified. This is particularly so in so far as the apparent reciprocal differences for leaf-number could also complicate the picture by giving spurious epistatic effects.

In the development of the young grass seedling, new tillers arise in the axils of leaves and, as may be expected, there is a high positive correlation between leaf and tiller number $\left(r=0.96^{* * *}\right)$. This is 

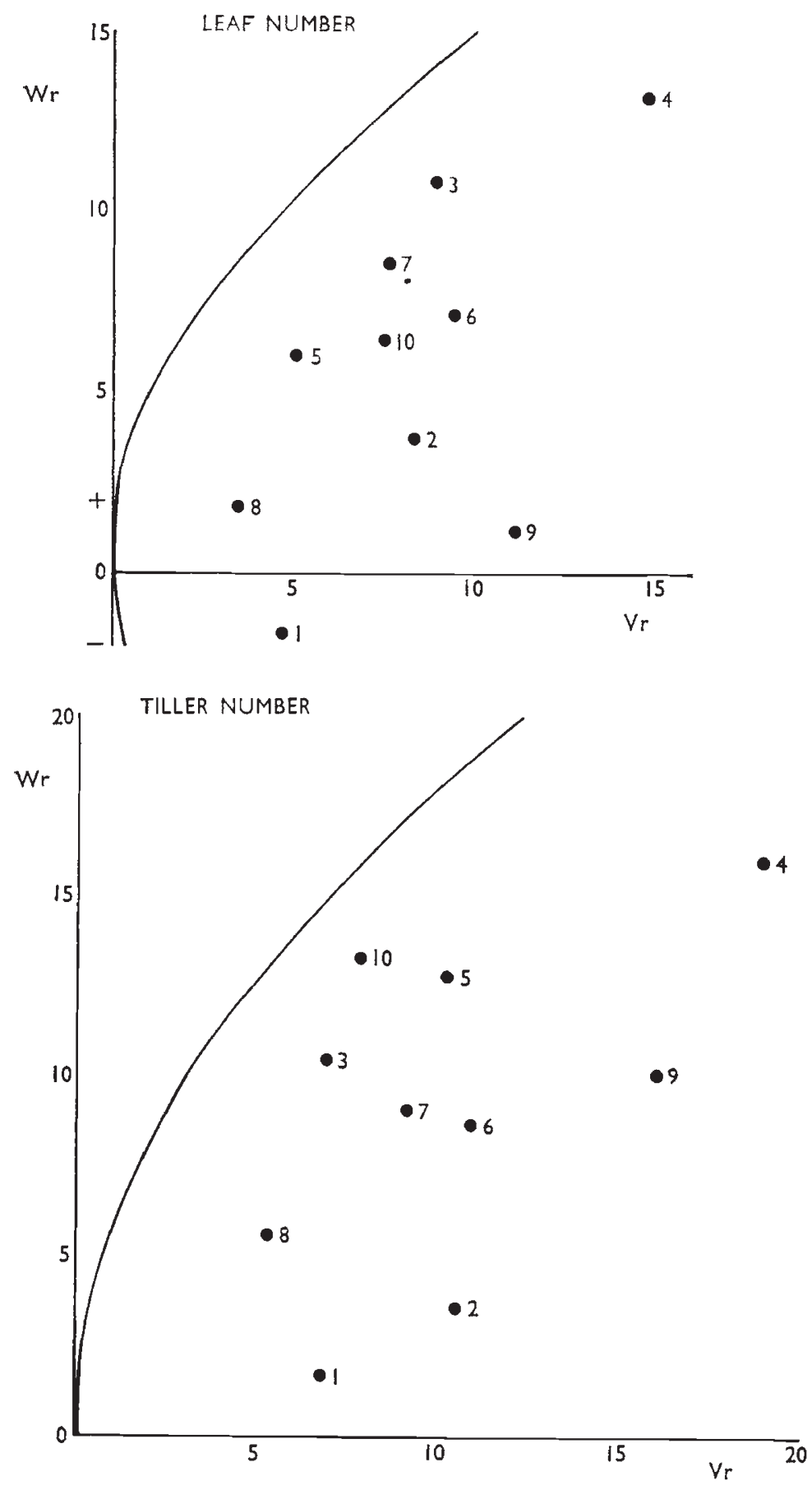

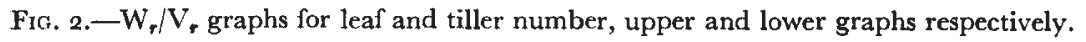


reflected in the two $W_{r} / V_{r}$ graphs, for the points fall in a similar pattern for the two characters $\left(r=0 \cdot 78^{* * *}\right)$.

(iv) Length of the 5 th leaf

The length of the fully expanded fifth leaf was measured, sixty days after sowing, on fifteen plants per family of only one replicate (table 8). As the measurements were restricted to a single replicate, the usual analysis of variance is somewhat limited in its application.

TABLE 8

Mean length of 5 th leaf

\begin{tabular}{|c|c|c|c|c|c|c|c|c|c|c|}
\hline & I & 2 & 3 & 4 & 5 & 6 & 7 & 8 & 9 & Io \\
\hline $\begin{array}{r}\text { I } \\
2 \\
3 \\
4 \\
5 \\
6 \\
7 \\
8 \\
9 \\
10\end{array}$ & $\begin{array}{r}9.43 \\
8.44 \\
7.29 \\
\mathrm{II} \cdot 3 \mathrm{I} \\
7.5 \mathrm{I} \\
7.28 \\
\mathrm{I} 0 . \mathrm{II} \\
\mathrm{IO} \cdot 38 \\
6.37 \\
9.67\end{array}$ & $\begin{array}{r}8 \cdot 10 \\
6 \cdot 53 \\
8 \cdot 64 \\
10 \cdot 49 \\
10 \cdot 75 \\
6 \cdot 92 \\
7 \cdot 76 \\
10 \cdot 59 \\
7 \cdot 22 \\
9.59\end{array}$ & $\begin{array}{l}7 \cdot 61 \\
8 \cdot 39 \\
6 \cdot 68 \\
9 \cdot 23 \\
8 \cdot 01 \\
7 \cdot 86 \\
7 \cdot 10 \\
9 \cdot 30 \\
6 \cdot 73 \\
7 \cdot 93\end{array}$ & $\begin{array}{r}10 \cdot 07 \\
\text { 10.96 } \\
8 \cdot 29 \\
\text { 11.27 } \\
8 \cdot 26 \\
9 \cdot 48 \\
\text { 10.93 } \\
8 \cdot 98 \\
6 \cdot 44 \\
\text { 10.24 }\end{array}$ & $\begin{array}{r}8 \cdot 15 \\
6 \cdot 27 \\
8 \cdot 75 \\
9 \cdot 10 \\
7 \cdot 14 \\
10 \cdot 35 \\
9 \cdot 64 \\
7 \cdot 94 \\
4 \cdot 84 \\
11 \cdot 12\end{array}$ & $\begin{array}{r}7 \cdot 67 \\
7 \cdot 1 \mathrm{I} \\
8 \cdot 76 \\
10 \cdot 47 \\
8 \cdot 45 \\
8 \cdot 43 \\
9 \cdot 32 \\
7 \cdot 81 \\
5 \cdot 49 \\
9 \cdot 13\end{array}$ & $\begin{array}{r}10.05 \\
10 \cdot 18 \\
9 \cdot 82 \\
9 \cdot 36 \\
\text { I0.93 } \\
7 \cdot 71 \\
8 \cdot 25 \\
9 \cdot 18 \\
7.05 \\
8.53\end{array}$ & $\begin{array}{r}8.53 \\
7.68 \\
7.81 \\
12.06 \\
8.98 \\
7.41 \\
8.07 \\
8.79 \\
6.97 \\
10.29\end{array}$ & $\begin{array}{l}6 \cdot 57 \\
7 \cdot 49 \\
6 \cdot 92 \\
6 \cdot 50 \\
5 \cdot 71 \\
6 \cdot 44 \\
6 \cdot 29 \\
8 \cdot 24 \\
4 \cdot 55 \\
8 \cdot 27\end{array}$ & $\begin{array}{r}\mathrm{I} 1 \cdot 25 \\
8 \cdot 99 \\
9 \cdot 13 \\
\mathrm{I} 0.45 \\
7 \cdot 99 \\
9 \cdot 65 \\
6 \cdot 36 \\
8 \cdot 74 \\
3 \cdot 79 \\
\mathrm{I} 0.09\end{array}$ \\
\hline
\end{tabular}

TABLE 9

Analysis of variance of mean length of the 5 th leaf

\begin{tabular}{|c|c|c|c|}
\hline Item & N. & M.S. & V.R. \\
\hline$a$ & 9 & $\mathrm{I} 5 \cdot 95$ & $\mathrm{II} \cdot \mathrm{O}^{* * * *}$ \\
\hline$b$ & 45 & $\mathrm{I} \cdot 33$ & \\
$c$ & 9 & $\mathrm{I} \cdot 40$ & \\
$d$ & 36 & $\mathrm{I} \cdot 34$ & \\
\hline $\begin{array}{c}\text { Pooled } \\
\text { Error }\end{array}$ & 90 & $\mathrm{I} \cdot 34$ & \\
\hline & & \\
\hline
\end{tabular}

Wearden (1964) has critically assessed the validity of the various alternative methods of analysing a diallel scheme. The present experiment falls into the category of random sampling. Within this scheme there are two possible models to consider, that for maternal effects and that for reciprocal effects. In the absence of replicates we have no test of significance for reciprocal differences as measured by $(d)$. Tested against $(d)$, neither $(c)$, measuring constant maternal effects, nor $(b)$, measuring dominance and epistasis, is significant. These three items may be pooled therefore to test $(a)$ which measures the additive portion of the genic variance (see table 9). By this test (a) 
is highly significant showing that the variation between populations is largely due to additive gene action.

In contrast to the analysis of variance, the $\mathrm{W}_{r} / \mathrm{V}_{r}$ graphs are more informative in that they have a greater sensitivity in detecting dominance (see Hill, I964). The graph is presented in fig. 4. The regression of $\mathrm{W}_{r}$ on $\mathrm{V}_{r}$ is significant and closely approximates to unity, suggesting

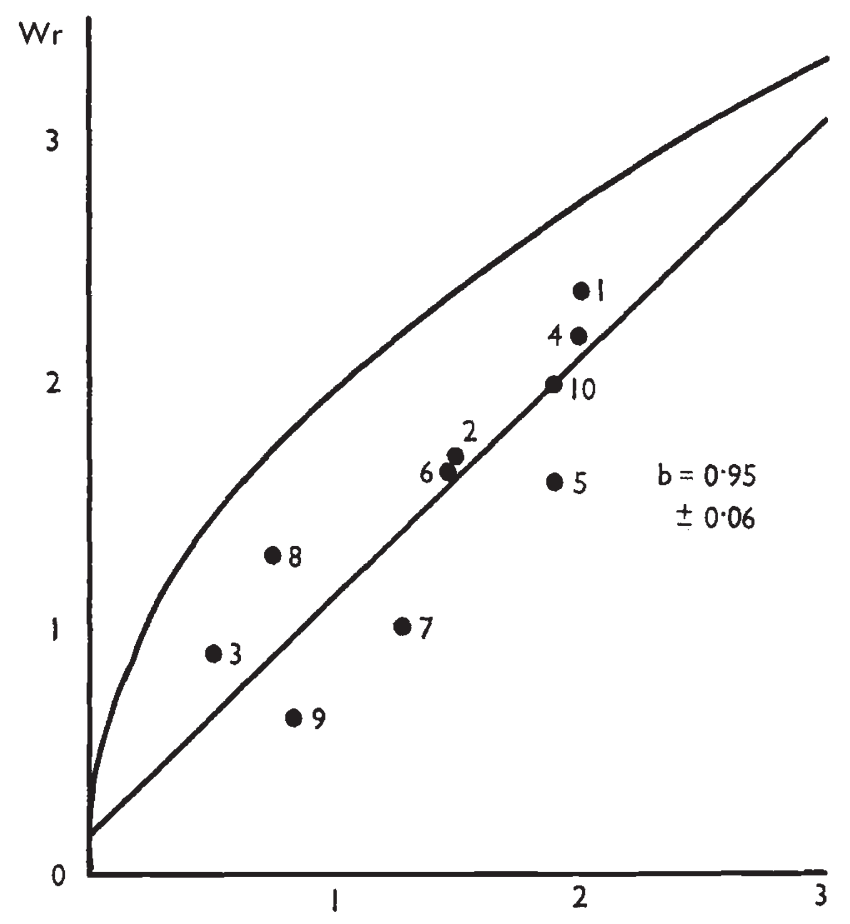

Frg. 3. $-W_{r} / V_{r}$ graph for length of $5^{\text {th leaf. }}$

a degree of dominance. It must be remembered, however, that no attempt has been made to correct the graph for error in the absence of replication. Furthermore, from the analysis of variance the dominance component is no greater than that of the reciprocal items, the effects of which may be to simulate dominance. The correlation of $\left(\mathrm{W}_{r}+\mathrm{V}_{r}\right)$ with the parental value is positive and significant $(r=0.7 \mathrm{I}$ and $\mathrm{P}=0.05-0.02$ ), indicating that any dominance is for short leaf length. Indeed the most dominant parent (9) has extremely short leaves which average only $4.5 \mathrm{~cm}$. compared with an overall average of 10.29 for the recessive parents 10,4 and $\mathrm{I}$.

\section{DISCUSSION}

Previous studies on the genetic variation in seed and seedling characters in Lolium perenne have considered populations which are either local strains forming commercial varieties (Cooper, $196 \mathrm{r}$; Cooper and Edwards, 1961; Edwards and Cooper, 1963), or plants 
forming the basis of a breeding project (Beddows, et al., I962). It is of interest, therefore, to consider the results of the present study in relation to the origin of the material, and to compare them with the results obtained by the previous authors.

The results of studies on self- and cross-fertility follow the pattern of those presented by Beddows $e t$ al. (loc cit) in certain characteristics only. The latter authors suggest that some incomplete form of an incompatibility mechanism is operating in the ryegrasses. The high degree of self-sterility obtained in the present study may tentatively be considered as evidence for the operation of such a system; however, other factors, such as the highly artificial conditions under which the measurements are made, seriously limit the drawing of any firm conclusions about this mechanism.

The amount of seed set on selfing was markedly lower than that found by Beddows $\mathrm{et}$ al. These authors, however, found good evidence of a decline in seed setting ability with increasing age of the clone over the three-year period studied. The plants used in the present study are probably extremely old, being clonal propagates from vegetative material collected from very old swards. Just how old these clones might be is difficult to determine, but it is interesting to note that Harberd (1962) suggests that Festuca ovina plants, collected from intensively grazed pastures, may be centuries old. It may well be that the low seed-set is therefore a reflection of clonal age. At this low level of seed-set, any differences between populations would be masked by the high environmental variation which exists between selfing units.

The striking feature of the inter-population crosses was again the very low average seed-set ( 7 per cent as compared with 42 per cent obtained by Beddows $e t a l$.). There were significant differences between populations and the analyses showed that this variation was in respect of both male and female fertilities. However, the variation in male fertility was largely due to the low pollen production of parent io and, after removing this array, the residual variation appeared to be mainly maternal in origin. Whether the general low order of seedset is due to maternal or paternal influences or to both, can only be determined by test out-crosses and these have not yet been performed. Although accurate seed counts were not taken from the intra-population polycrosses, the level of fertility appeared to be no higher than in the inter-population crosses.

The association of low seed fertility with a perennial habit has been noted previously (Beddows, I93I; Williams, I95I; and Stebbins, 1950). Under the conditions existing in closely grazed swards it is, of course, unlikely that the sexual phase will have been important after initial establishment, survival thereafter being a question of perenniality or, more accurately, continued asexual propagation. Whether the low fertility observed in these experiments is due, at least in part, to a genetic correlation with a high capacity for tillering, or whether it is an effect of clonal age as prognosticated in the experiment 
of Beddows et al. has yet to be determined. Obviously the distinction is of major importance from the plant breeding point of view.

The germination results are in effect an extension of the seed-setting results, in that they reflect on the production of fertile seeds. Despite the fact that during threshing operations all seeds without fully developed caryopses were screened off, there were still significant differences between populations. The greatest part of this variation can be ascribed to additive gene action, but there are also dominance effects. The large item for mean dominance $\left(b_{1}\right.$ in table 5$)$-must, however, be treated with some caution since it will include confounded environmental effects, polycross and $F_{1}$ seed having been produced in two different environments. The $\mathrm{W}_{r} / \mathrm{V}_{r}$ graphs indicate that dominance is in the direction of high germination capacity, indicating a past history of unidirectional selection for this character.

Assuming that the higher values for crosses between populations, in comparison with those for crosses within, are not entirely due to a different environment, these seed-viability results are comparable to those noted by Breese and Mather (1960) for viability among Drosophila populations. These authors pointed out that, although in a sexually reproduced species there will be an overall directional selection for viability of offspring, within any one population the selection pressure will not necessarily be so great as to ensure the maximum viability possible. In the present instance, where asexual reproduction features largely, the comparatively low values of the intra-population crosses can be taken as evidence of a relaxed selection pressure for viability in sexual offspring. Undoubtedly there are differences between the populations with regard to the extent this relaxation has occurred, and part of this may be explained by random drift. At present our notes on the length of duration of the sward are not sufficient to determine whether there is also a correlation between differences in persistency and decline in germination.

Turning to the seedling results, the analyses for leaf and tiller number show that additive effects form the main component of variation between the populations studied. Dominance may also feature to a small extent, but the complex scatter of points in the $W_{r} / V_{r}$ graphs does not allow us to interpret this situation any further, especially because dominance effects are barely significant in comparison with reciprocal differences. This situation agrees in broad principles with that described by Cooper and Edwards ( $196 \mathrm{I}$ ) in studies with seedling characters of cultivars of $L$. perenne. It would appear that there has been little directional selection for these characters at least during the immediate past. The similar genetic patterns for both leaf and tiller number suggest a close genetic correlation between there two characters. Indeed, this is not surprising since the leaf axil forms the site on which the tiller is developed. However, as Cooper and Edwards (loc cit) have shown, this association is not irrevocable since there can be a delay in the onset of tillering or even a failure in the development of 
tillers at various sites. Thus each system can have a measure of independent genetic control. If we are to assume anything from the associated genetic control in the present instance, it is that tillering, or asexual reproduction, is at this early stage at the maximum of the limits set by the rate of leaf production.

In the case of the length of fifth leaf the additive component is again of major importance. The $\mathrm{W}_{r} / \mathrm{V}_{r}$ graphs do show, however, a degree of dominance and notably this is the direction of small leaf size. This may be taken as an indication that there has been some directional selection for the short leaf character, a not unreasonable assumption, in that short leaves might be presumed less susceptible to the rigours of close grazing and hence of advantage at the time of initial sward establishment, or in procuring some degree of seedling establishment during the history of the sward.

There is one other notable feature which applies to all the analyses of seedling characters. In each instance, although there is little sign of constant maternal effects, there is good evidence of residual reciprocal differences. This has to be regarded with some caution since the plants were not emasculated, and inadvertent selfing through incomplete self-incompatibility could add to these effects. Nevertheless, since the degree of selfing in test units was extremely low, we may regard these reciprocal differences as indicating some form of nuclear cytoplasmic interaction. This is extremely interesting in view of the results reported by Breese et al. (loc cit), wherein they find evidence of a plasmoncontrolled system of variability, but which was itself predisposed by a particular genotypic constitution.

By and large the results are reasonably clear. There is a general degeneration of the sexual process with an extremely low seed-set and variable germination. Of the seedling characters only the length of the $5^{\text {th }}$ leaf shows much evidence of directional selection, while both tiller- and leaf-production rates show mainly additive variation from which it may be inferred that either past selection has been stabilising or has not been particularly intense. Indeed, with regard to germination there is good evidence that within the populations selection has been relaxed in comparison with the archetypal population from which they have become differentiated.

This situation is not, of course, surprising in populations which owe their being chiefly to a faculty for asexual reproduction. The findings are not inconsistent with agronomic experience with persistent ecotypes and cultivars which can be shy-seeders and are often notoriously difficult in establishment. Breese et al. (loc cit) have put forward the theory that plasmon lability may be important in the advance to sward equilibrium. In the present study there are hints of a cytoplasmic influence and a nuclear/cytoplasmic interaction. The association between poor seed setting and establishment with good asexual properties may not, therefore, be inevitable. It may be more a question of obtaining the right nucleus in the right cytoplasm. 


\section{SUMMARY}

I. The genetic basis of population differentiation in seed and seedling characters in ten populations of Lolium perenne has been examined by means of a diallel cross. The populations utilized were a representative sample of a much larger collection made from a series or permanent pastures known as the Monmouthshire Moors area of South East Wales.

2. The populations were characterised by an extremely low seedset on both selfing and crossing, indicating that there had been a general degradation of the sexual process.

3. Germination was variable, but it was generally lower in seed from crosses within populations than in seed from crosses between populations. This suggests that within the populations selection for this character had been relaxed in comparison with the archetypal population from which they had become differentiated.

4. For leaf- and tiller-number the genetic variation between populations was mainly additive, suggesting very little directional selection. There is some evidence, however, that the rate of tiller reproduction (asexual reproduction) was at the maximum of the limits set by the rate of leaf production. The length of the fifth leaf also showed mainly additive genetic variation, but in this case some degree of dominance for shorter leaf was apparent.

5. Although there was little sign of constant maternal effects, there was good evidence of residual reciprocal differences. This has been interpreted as indicating some form of nuclear/cytoplasmic interaction.

6 . The results are discussed in relation to the past history of the populations, particularly with regard to the role of asexual reproduction in tiller survival.

Acknowledgments.-We wish to thank the Director of the Welsh Plant Breeding Station, Professor P. T. Thomas, for his interest in this work.

\section{REFERENCES}

BEDDows, A. R. I931. Seed setting and flowering in various grasses. Bull. Welsh Pl. Breed. Sta., Ser. H, I2, 5 .

BEDDOWS, A. R., BREESE, E. L., AND LEWIS, B. 1962. The genetic assessment of heterozygous breeding material by means of a diallel cross. 1. Description of parents, self- and cross-fertility and early seedling vigour. Heredity, I7, 501$5 \mathrm{I} 2$.

BREESE, E. L. 1956. The genetical consequences of assortative mating. Heredity, ro, 323-343.

BREESE, E. L. 1965. Reproduction in ryegrasses. Paper presented to Conference on "Reproductive Biology and Taxonomy of Vascular Plants". B.S.B.I.

BREESE, E. L., HAYWARD, M. D., AND THOMAS, A. C. 1965. Somatic selection in perennial ryegrass Lolium perenne L. Heredity (in press).

BReESE, E. L., AND Gharles, A. H. 1962. Population studies in ryegrass. Rep. Welsh Pl. Breed. Stn., 1959, 30-34.

BREESE, E. L., AND MATHER, K. I96o. The organisation of polygenic activity within a chromosome in Drosophila. II. Viability. Heredity, I4, 375-40I. 
COOPER, J. P. 1959. Selection and population structure in Lolium. III. Selection for date of ear emergence. Heredity, ${ }_{3}, 46 \mathrm{I}-479$.

COOPER, J. P. 196r. Selection and population structure in Lolium. V. Continued response and associated changes in fertility and vigour. Heredity, I6, 435-453. COOPER, J. P., AND EDWARDS, K. J. R. 196r. The genetic control of leaf development in Lolium. I. Assessment of genetic variation. Heredity, $16,63-82$.

Darlington, C. D. 1939. Evolution of Genetic Systems. Cambridge University Press. DARLington, C. D., AND MATHER, K. 1949. The Elements of Genetics. Allen \& Unwin, London.

DIGKINSON, A. G., AND Jinks, J. L. I956. A generalised analysis of diallel crosses. Genetics, 4I, 65-78.

EDWARDS, K. J. R., AND GOOPER, J. P. 1963 . The genetic control of leaf development in Lolium. II. Response to selection. Heredity, $18,307-317$.

HARBerd, D. J. 1962. Some observations on natural clones in Festuca ovina. New Phytol., 6I, 85-100.

HAYMAN, в. 1. 1954a. The analysis of variance of diallel tables. Biometrics, Io, 235-244.

hayman, B. I. 1954b. The theory and analysis of diallel crosses. Genetics, 39, 789809 .

HILL, J. 1964. Effects of correlated gene distributions in the analysis of diallel crosses. Heredity, 19, 27-46.

JENKIN, T. J. I931 $a$. The breeding of herbage plants. Methods and technique of selection, breeding and strain-building in grasses. Bull. Bur. Pl. Genet. Aberystw., 3, $\mathrm{I}-34$.

JENKIN, T. J. 1931 $b$. Self-fertility in perennial ryegrass (Lolium perenne L.). Bull. Welsh Pl. Breed. Sta., Ser. H., I2, roo-1 19.

JINKS, J. L. 1954. The analysis of continuous variation in a diallel cross of Nicotiana rustica varieties. Genetics, 39, 767-788.

MATHER, K., AND haRrison, B. J. 1949. The manifold effect of selection. Heredity, $3,1-52,131-162$.

Stebrins, G. L. I950. Variation and Evolution in Plants. Columbia University Press, New York.

WEARDEN, s. 1964. Alternative analyses of the diallel cross. Heredity, 19, 669-68o. WHYTE, R. O., MOIR, T. R. G., AND COOPER, J. P. 1959. Grasses in Agriculture. F.A.O., Rome.

williams, w. 1951. Genetics of incompatibility in alsike clover, Trifolium hybridum. Heredity, 5, 5 1-73.

YATES, F. 1947- Analysis of data from all possible reciprocal crosses between a set of parental lines. Heredity, $I, 287-30 \mathrm{I}$. 